\title{
Qualitative Visual Image Analysis of Bruise Age Determination: A Survey
}

\author{
T. Dimitrova, L. Georgieva, C. Pattichis, Member IEEE, M. Neofytou, Student Member IEEE
}

\begin{abstract}
The evaluation of bruise color imaging is a very important task in forensic medicine. However, there is no standardized methodology in carrying out this task. In this paper, an attempt was made to review the different papers published in the literature on the visual assessment of bruise age determination, and derive color charts of daily bruise aging. Based on the color charts derived, the following observations can be made: (i) the bruise is red for day 1 , (ii) there is no dominant color for day 2 , whereas for day 3 , blue is becoming slightly dominant, (iii) green is becoming dominant for days 4-6, with yellow color emerging, (iv) for day 7 , there is coexistence of green and yellow, (v) yellow is highly dominant for days 7 to 14, with brown emerging. These charts can serve as guidelines for the qualitative evaluation of bruise imaging by visual analysis. Clearly, the need exists for the quantitative analysis of bruise color imaging.

Keywords - bruise imaging, bruise aging, visual assessment, color.
\end{abstract}

\section{INTRODUCTION}

$\mathrm{T}$ HE determination of the age of a bruise is an important aspect of forensic medicine. Estimation of the age of a bruise in forensic practice is based on the determination of the colors by visual inspection (see Fig. 1). However, this is a very subjective method, because the results depend on many factors - forensic physicians experience, color distribution, room illumination, color of the skin and other. Given these facts, there is a great disagreement among the different studies published in the color distribution of bruises with aging. Moreover, to the best of our knowledge there are no papers published addressing the issue of quantitative analysis of bruise aging. The objective of this paper is to provide a survey of the different methods published in the literature for quality visual image analysis of bruise age determination.

A bruise is also called a contusion, and it forms because the soft tissues of the body have been injured. Some people bruise easily, whereas others may have a tougher skin tissue. When these soft tissues are injured, small veins and capillaries (the tiniest blood vessels) under the skin sometimes break and red blood cells leak out. It is the

Manuscript received April 15, 2006.

T. V. Dimitrova is with the Computer System and Technologies Department, Rousse University, Rousse, Bulgaria (e-mail: tdimitrova@ecs.ru.acad.bg).

C. S. Pattichis is with Computer Science Department, University of Cyprus, Nicosia, Cyprus. (e-mail: pattichis@ucy.ac.cy).

L. H. Georgieva is with the Computer System and technologies Department, Rousse University, Rousse, Bulgaria (e-mail: lgeorgieva@ecs.ru.acad.bg).

M. S. Neofytou is with Computer Science Department, University of Cyprus, Nicosia, Cyprus. (e-mail: mneoph@ucy.ac.cy). accumulation of these red blood cells under the human skin that cause a bluish, purplish, reddish, or blackish mark.

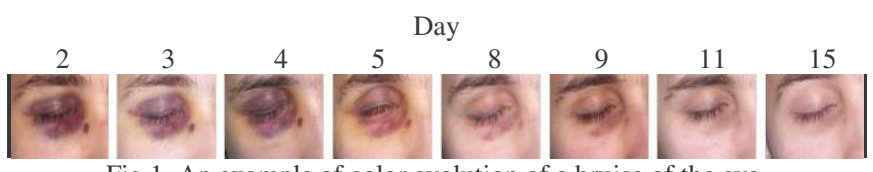

Fig.1. An example of color evolution of a bruise of the eye.

Usually, there is a typical appearance and consequent disappearance of a few colors during the process of healing (see Fig.1), e.g. from black-red (the color of hem), through green to yellow [1]. These changes are attributed to the process of haemoglobin degradation. Some of the products of haemoglobin breakdown are biliverdin (producing the greenish color) and bilirubin (producing the yellowish color). A bruise disappears after two weeks whereas some bruises may disappear even earlier.

Different methods have been published in the literature for the assessment of color bruise imaging based on visual assessment (see Table II), including digital photography [2] and spectrophotometry [3]. However, it seems that the most widely used technique is the visual assessment. In this paper a survey of visual papers is given.

The structure of the paper is as follows. In section II, problem definition is given, section III presents a survey of the studies published on color visual bruise aging and section VI presents the concluding remarks.

TABLE I

BRUISE AGING COLOR MAP

\begin{tabular}{cccccc}
\hline № & Name & $\begin{array}{c}\text { Abbrev } \\
\text { iation }\end{array}$ & № & Name & $\begin{array}{c}\text { Abbrev } \\
\text { iation }\end{array}$ \\
\hline 1 & Purple-Black & P-K & 11 & Blue-Black & B-K \\
2 & Dark Purple & DP & 12 & Dark Blue & DB \\
3 & Purple & P & 13 & Red-Blue & R-B \\
4 & Dark Red & DR & 14 & Violet & V \\
5 & Red & R & 15 & Livid Red & LR \\
6 & Pink & PK & 16 & Brown & BR \\
7 & Yellow & Y & 17 & Blue-Brown & B-BR \\
8 & Yellow-Green & Y-G & 18 & Yellow-Brown & Y-BR \\
9 & Green & G & 19 & Black & K \\
10 & Blue & B & & & \\
\hline
\end{tabular}

\section{PROBlEM DEFINITION}

Forensic experts are often confronted with questions regarding the age of injuries. This is a very difficult task, especially when it is needed to accurately determine the age of a bruise in a living person. The only indicator of the age of a bruise is the color distribution and pattern of the injury. The main question is: when do the colors change, and which colors are the significant ones. 
TABLE II

AN OVERVIEW OF QUALITATIVE VISUAL IMAGE ANALYSIS STUDIES OF BRUISE AGE DETERMINATION. (SEE TABLE I FOR THE COLOR ABBREVIATIONS USED AND FIG. 3 FOR A GRAPHICAL COLOR REPRESENTATION OF BRUISE AGING)

\begin{tabular}{|c|c|c|c|c|c|c|c|c|c|c|c|c|c|c|c|}
\hline \multirow{2}{*}{ Study } & \multirow{2}{*}{$\begin{array}{c}\text { № } \\
\text { of } \\
\text { subj } \\
\text { ects } \\
\text { /bru } \\
\text { ises }\end{array}$} & \multicolumn{14}{|c|}{ Daily color appearance } \\
\hline & & Day 1 & Day 2 & Day 3 & Day 4 & Day 5 & Day 6 & Day 7 & Day 8 & Day 9 & $\begin{array}{c}\text { Day } \\
10\end{array}$ & $\begin{array}{c}\text { Day } \\
11\end{array}$ & $\begin{array}{c}\text { Day } \\
12\end{array}$ & $\begin{array}{c}\text { Day } \\
13\end{array}$ & $\begin{array}{c}\text { Day } \\
14\end{array}$ \\
\hline $\begin{array}{c}\text { Steph. } \\
{[2],[6]}\end{array}$ & $\begin{array}{l}23 / \\
44\end{array}$ & $\mathrm{R}$ & $\mathrm{R}, \mathrm{Y}$ & $\mathrm{R}, \mathrm{Y}$ & $\mathrm{R}, \mathrm{Y}$ & $\mathrm{R}, \mathrm{Y}$ & $\mathrm{R}, \mathrm{Y}$ & $\mathrm{Y}$ & $\mathrm{Y}$ & $\mathrm{Y}$ & Y & Y & $\mathrm{Y}$ & $\mathrm{Y}$ & $\mathrm{Y}$ \\
\hline $\begin{array}{l}\text { Baricia } \\
\mathrm{k}[10]\end{array}$ & $\begin{array}{l}50 / \\
50\end{array}$ & $\begin{array}{l}\mathrm{P}, \mathrm{R}, \\
\mathrm{B}\end{array}$ & $\begin{array}{l}\mathrm{P}, \mathrm{R}, \\
\mathrm{B}\end{array}$ & - & - & - & - & $\begin{array}{c}\mathrm{P}, \mathrm{R} \\
\mathrm{Y}, \mathrm{G}, \\
\mathrm{B}, \mathrm{BR}\end{array}$ & $\begin{array}{c}\mathrm{P}, \mathrm{R}, \\
\mathrm{Y}, \mathrm{G}, \\
\mathrm{B}, \mathrm{BR}\end{array}$ & $\begin{array}{c}\mathrm{P}, \mathrm{R}, \\
\mathrm{Y}, \mathrm{G}, \\
\mathrm{B}, \mathrm{BR}\end{array}$ & $\begin{array}{c}\mathrm{P}, \mathrm{R} \\
\mathrm{Y}, \mathrm{G}, \\
\mathrm{B}, \mathrm{BR}\end{array}$ & $\begin{array}{c}\mathrm{P}, \mathrm{R}, \\
\mathrm{Y}, \mathrm{G}, \\
\mathrm{B}, \mathrm{BR}\end{array}$ & $\begin{array}{c}\mathrm{P}, \mathrm{R}, \\
\mathrm{Y}, \mathrm{G}, \\
\mathrm{B}, \mathrm{BR}\end{array}$ & $\begin{array}{c}\mathrm{P}, \mathrm{R}, \\
\mathrm{Y}, \mathrm{G}, \\
\mathrm{B}, \mathrm{BR}\end{array}$ & $\begin{array}{l}\mathrm{P}, \mathrm{R}, \\
\mathrm{Y}, \mathrm{G}, \\
\mathrm{B}, \mathrm{BR}\end{array}$ \\
\hline $\begin{array}{c}\text { Langloi } \\
\mathrm{s}[4]\end{array}$ & $\begin{array}{r}89 / \\
369\end{array}$ & $\begin{array}{c}\mathrm{P}-\mathrm{K}, \\
\mathrm{R}, \mathrm{Y} \\
\mathrm{B}\end{array}$ & $\begin{array}{c}\mathrm{P}-\mathrm{K} \\
\mathrm{R}, \mathrm{Y} \\
\mathrm{B}\end{array}$ & $\begin{array}{c}\mathrm{P}-\mathrm{K} \\
\mathrm{R}, \mathrm{Y} \\
\mathrm{B}\end{array}$ & $\begin{array}{c}\mathrm{P}-\mathrm{K}, \\
\mathrm{R}, \mathrm{Y} \\
\mathrm{B}\end{array}$ & $\begin{array}{c}\mathrm{P}-\mathrm{K}, \\
\mathrm{R}, \mathrm{Y} \\
\mathrm{B}\end{array}$ & $\begin{array}{l}\mathrm{P}-\mathrm{K}, \\
\mathrm{R}, \mathrm{Y}, \\
\mathrm{B}\end{array}$ & $\begin{array}{c}\mathrm{P}-\mathrm{K}, \\
\mathrm{R}, \mathrm{Y}, \\
\mathrm{B}\end{array}$ & $\begin{array}{c}\mathrm{P}-\mathrm{K}, \\
\mathrm{R}, \mathrm{Y} \\
\mathrm{B}\end{array}$ & $\begin{array}{c}\mathrm{P}-\mathrm{K}, \\
\mathrm{R}, \mathrm{Y}, \\
\mathrm{B}\end{array}$ & $\begin{array}{c}\mathrm{P}-\mathrm{K} \\
\mathrm{R}, \mathrm{Y} \\
\mathrm{B}\end{array}$ & $\begin{array}{c}\mathrm{P}-\mathrm{K}, \\
\mathrm{R}, \mathrm{Y} \\
\mathrm{B}\end{array}$ & $\begin{array}{c}\mathrm{P}-\mathrm{K}, \\
\mathrm{R}, \mathrm{Y} \\
\mathrm{B}\end{array}$ & $\begin{array}{c}\mathrm{P}-\mathrm{K} \\
\mathrm{R}, \mathrm{Y} \\
\mathrm{B}\end{array}$ & $\begin{array}{l}\text { P-K, } \\
\text { R, Y, } \\
\quad \text { B }\end{array}$ \\
\hline $\begin{array}{c}\text { Smith } \\
{[11]}\end{array}$ & - & $\mathrm{R}$ & $\mathrm{P}, \mathrm{K}$ & $\begin{array}{c}\mathrm{P}, \mathrm{Y}, \\
\mathrm{K}\end{array}$ & G & G & - & $\mathrm{Y}$ & Y & $\mathrm{Y}$ & Y & - & - & - & - \\
\hline $\begin{array}{c}\text { Glaist. } \\
\text { [12] }\end{array}$ & - & V & V & $\mathrm{B}$ & B & G & G & G & $\mathrm{Y}$ & $\mathrm{Y}$ & Y & - & - & - & - \\
\hline $\begin{array}{c}\text { Adels. } \\
\text { [13] }\end{array}$ & - & $\begin{array}{c}\text { R-B, } \\
\text { B-BR }\end{array}$ & $\mathrm{B}, \mathrm{BR}$ & $\mathrm{B}, \mathrm{BR}$ & - & - & - & Y-G & - & - & - & - & - & - & - \\
\hline $\begin{array}{c}\text { Camps } \\
{[14]}\end{array}$ & - & $\begin{array}{l}\mathrm{P}, \mathrm{R}, \\
\mathrm{K}\end{array}$ & $\mathrm{DP}, \mathrm{K}$ & DP, K & G & G & G & $\mathrm{Y}$ & Y & $\mathrm{Y}$ & $\mathrm{Y}$ & - & - & - & - \\
\hline $\begin{array}{l}\text { Rent. } \\
{[15]}\end{array}$ & - & $\mathrm{DB}, \mathrm{V}$ & DB & DB & - & - & - & G & $\mathrm{Y}$ & $\mathrm{Y}$ & $\mathrm{Y}$ & - & - & - & - \\
\hline $\begin{array}{l}\text { Spitz } \\
{[16]}\end{array}$ & - & R-B & DP & DP & - & - & - & G-Y & BR & BR & BR & - & - & - & - \\
\hline $\begin{array}{c}\text { Sadle } \\
{[17]}\end{array}$ & - & $\begin{array}{l}\text { DP, } \\
\text { DR, } \\
\text { BR }\end{array}$ & BR & $\mathrm{BR}$ & G & $\mathrm{G}$ & G & $\mathrm{Y}, \mathrm{G}$ & $\mathrm{Y}, \mathrm{G}$ & $\mathrm{Y}, \mathrm{G}$ & $\mathrm{Y}, \mathrm{G}$ & $\mathrm{Y}, \mathrm{G}$ & $\mathrm{Y}, \mathrm{G}$ & $\mathrm{Y}, \mathrm{G}$ & $Y, G$ \\
\hline $\begin{array}{c}\text { Polson } \\
{[18]}\end{array}$ & - & $\begin{array}{l}\mathrm{DR}, \\
\mathrm{R}, \mathrm{K}\end{array}$ & $\mathrm{P}, \mathrm{K}$ & $\mathrm{P}, \mathrm{K}$ & - & - & - & G & - & - & - & - & - & - & $\mathrm{Y}$ \\
\hline $\begin{array}{c}\text { Hasan } \\
\text { [19] }\end{array}$ & - & $\mathrm{R}$ & DP & B & G & $\mathrm{G}$ & - & G & G & G & $\mathrm{G}$ & - & - & - & - \\
\hline $\begin{array}{c}\text { Braun. } \\
\text { [20] }\end{array}$ & - & $\underset{\mathrm{B}}{\mathrm{P}, \mathrm{R}}$ & $\begin{array}{l}\mathrm{P}, \mathrm{R}, \\
\mathrm{B}\end{array}$ & - & - & - & G & - & Y-BR & Y-BR & - & - & - & - & - \\
\hline $\begin{array}{c}\text { Farley } \\
\text { [21] }\end{array}$ & - & $\mathrm{R}$ & $\begin{array}{l}\mathrm{P}, \mathrm{R}, \\
\mathrm{B}\end{array}$ & $\mathrm{P}, \mathrm{B}$ & $\mathrm{P}, \mathrm{B}$ & $\begin{array}{l}\mathrm{P}, \mathrm{G}, \\
\mathrm{B}\end{array}$ & G & $\mathrm{Y}, \mathrm{G}$ & Y & $\mathrm{Y}$ & Y, BR & BR & BR & BR & BR \\
\hline $\begin{array}{c}\text { Saxena } \\
{[22]}\end{array}$ & - & $\begin{array}{l}\mathrm{R}, \mathrm{B}, \\
\mathrm{B}-\mathrm{K}, \\
\mathrm{LR}, \\
\mathrm{BR}\end{array}$ & $\begin{array}{c}\text { B, B- } \\
\text { K, LR, } \\
\text { BR }\end{array}$ & $\begin{array}{c}\text { B, B- } \\
\text { K, LR, } \\
\text { BR }\end{array}$ & - & $\mathrm{G}$ & $\mathrm{G}$ & Y & Y & $\mathrm{Y}$ & Y & $\mathrm{Y}$ & $\mathrm{Y}$ & $\mathrm{Y}$ & $\mathrm{Y}$ \\
\hline $\begin{array}{c}\text { Mosq. } \\
\text { [23] }\end{array}$ & $\begin{array}{l}101 / \\
108\end{array}$ & $\begin{array}{l}\mathrm{P}, \mathrm{R}, \\
\mathrm{Y}, \mathrm{G}, \\
\mathrm{B}, \mathrm{K}\end{array}$ & $\begin{array}{l}\mathrm{P}, \mathrm{R}, \\
\mathrm{Y}, \mathrm{G}, \\
\mathrm{B}, \mathrm{K}\end{array}$ & $\begin{array}{l}\mathrm{P}, \mathrm{R}, \\
\mathrm{Y}, \mathrm{G}, \\
\mathrm{B}, \mathrm{K}\end{array}$ & $\begin{array}{l}\mathrm{P}, \mathrm{R} \\
\mathrm{Y}, \mathrm{G} \\
\mathrm{B}, \mathrm{K}\end{array}$ & $\begin{array}{l}\mathrm{P}, \mathrm{R}, \\
\mathrm{Y}, \mathrm{G}, \\
\mathrm{B}, \mathrm{K}\end{array}$ & $\begin{array}{l}\mathrm{P}, \mathrm{R}, \\
\mathrm{Y}, \mathrm{G}, \\
\mathrm{B}, \mathrm{K}\end{array}$ & $\begin{array}{l}\mathrm{P}, \mathrm{R}, \\
\mathrm{Y}, \mathrm{G}, \\
\mathrm{B}, \mathrm{K}\end{array}$ & $\begin{array}{l}\mathrm{P}, \mathrm{R}, \\
\mathrm{Y}, \mathrm{G}, \\
\mathrm{B}, \mathrm{K}\end{array}$ & $\begin{array}{c}\mathrm{P}, \mathrm{R}, \\
\mathrm{Y}, \mathrm{G}, \\
\mathrm{K}\end{array}$ & $\begin{array}{l}\mathrm{P}, \mathrm{R}, \\
\mathrm{Y}, \mathrm{G}, \\
\mathrm{B}, \mathrm{K}\end{array}$ & $\begin{array}{l}\mathrm{P}, \mathrm{R} \\
\mathrm{Y}, \mathrm{G} \\
\mathrm{B}, \mathrm{K}\end{array}$ & $\begin{array}{c}\mathrm{P}, \mathrm{R} \\
\mathrm{Y}, \mathrm{B} \\
\mathrm{K}\end{array}$ & $\begin{array}{c}\mathrm{P}, \mathrm{R} \\
\mathrm{Y}, \mathrm{G}, \\
\mathrm{K}\end{array}$ & $\begin{array}{l}\mathrm{P}, \mathrm{R}, \\
\mathrm{Y}, \mathrm{K}\end{array}$ \\
\hline
\end{tabular}

The bruise color depends on many factors such as: parameters of the blow (i.e. force, direction and duration), characteristics of the object (i.e. its temperature and surface), caused injury, the place of the trauma on the body, intake of medicines, the biological and anatomical features of the subject (age, sex, body weight), blood 
disease (as hemophilia, cirrhosis and other), blood pressure, temperature of body, skin color and other [2], [4]-[6].

There is a great disagreement between the experts, whether the age of bruises can be determined qualitatively based on visual assessment or not. Some authors support that it is not possible to determine the age of a bruise visually [7], [8], whereas others have published guidelines for determining the bruise age [2], [4], [6]. Although there is a difference of opinions on the exact timing of the appearance of the different colors, there is a consensus that red, blue and purple are early colours, green appears after 4-7 days and yellow appears eighteen hours after injury. Hughes [9] suggested that the clinicians can examine a bruise and classify it as recent or old based on the presence of yellow color

\section{A SURVEY OF QUALITATIVE VISUAL IMAGE ANALYSIS STUDIES OF BRUISE AGE DETERMINATION}

Table I tabulates the colors used by the different experts for describing the age of the bruise. Colors were ordered based on their corresponding wavelength in the visible spectrum. The colors, which are a mixture (e.g. brown, black) were placed at the end of the table.

Table II gives more details of the different studies published in the literature on bruise color aging. In Table II, the first column gives the investigator, the second column the no. of subjects and the no. of bruises investigated, and the subsequent 14 columns give the bruise color distribution per day (coded as given in Table I).

Also, Fig. 2 gives a graphical color representation of bruise aging as tabulated in Table II. The percentage color frequency versus the 19 colors given in Table I is plotted for each day. For example, for day 1, 16 studies published color descriptions (see day 1 column in Table II). Consider for example, the paper by Bariciak [10] who presented that the day 1 colors are the purple, red, and blue. Although the percentage color distribution in no paper was given, it was assumed that the colors presented were equally distributed in the bruise image. So, in this case, $1 / 3,1 / 3$, and $1 / 3$ was given for the corresponding colors. This procedure was carried out for computing the histogram for day 1 for all 16 studies. The y axis of the histogram was then transformed to percentage format, with 16 corresponding to $100 \%$. The same procedure was carried out for all days. Thus, each chart in Fig. 2 represents the probability of colour distribution based on the published papers for each day.

The following conclusions can be made from Fig. 2:

- Day 1: The red color is dominant in day 1 with a $\%$ frequency close to $40 \%$, followed by red-blue and violet, with a $\%$ frequency of $10 \%$, and then blue and purple close to $10 \%$.
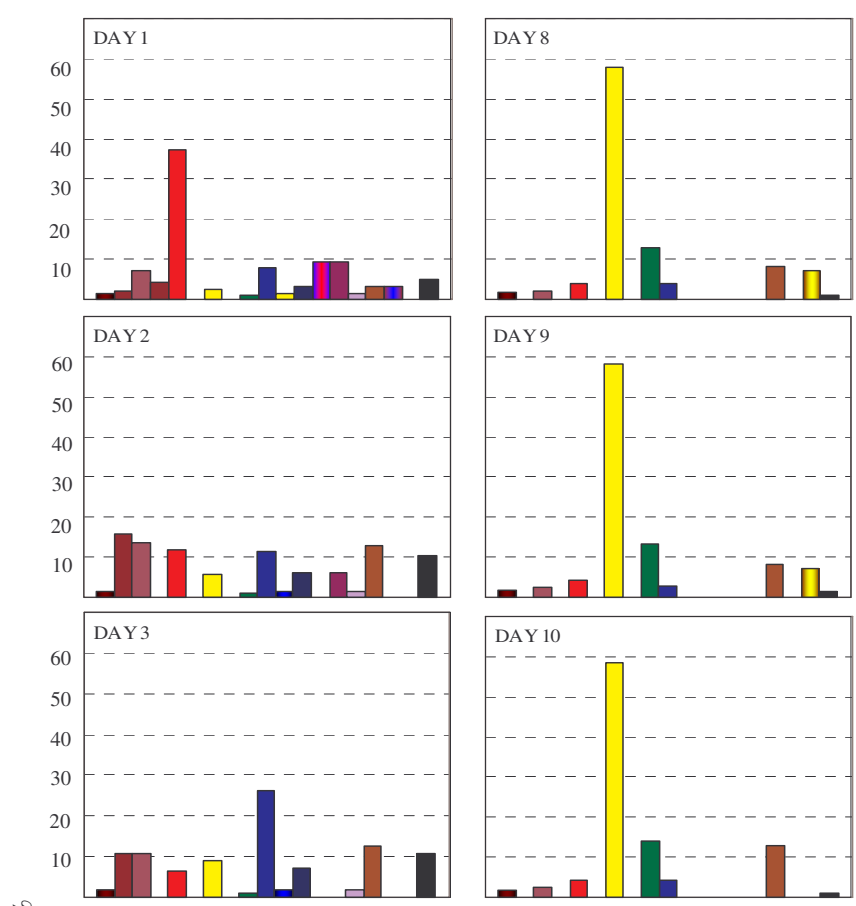

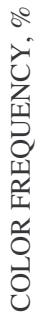
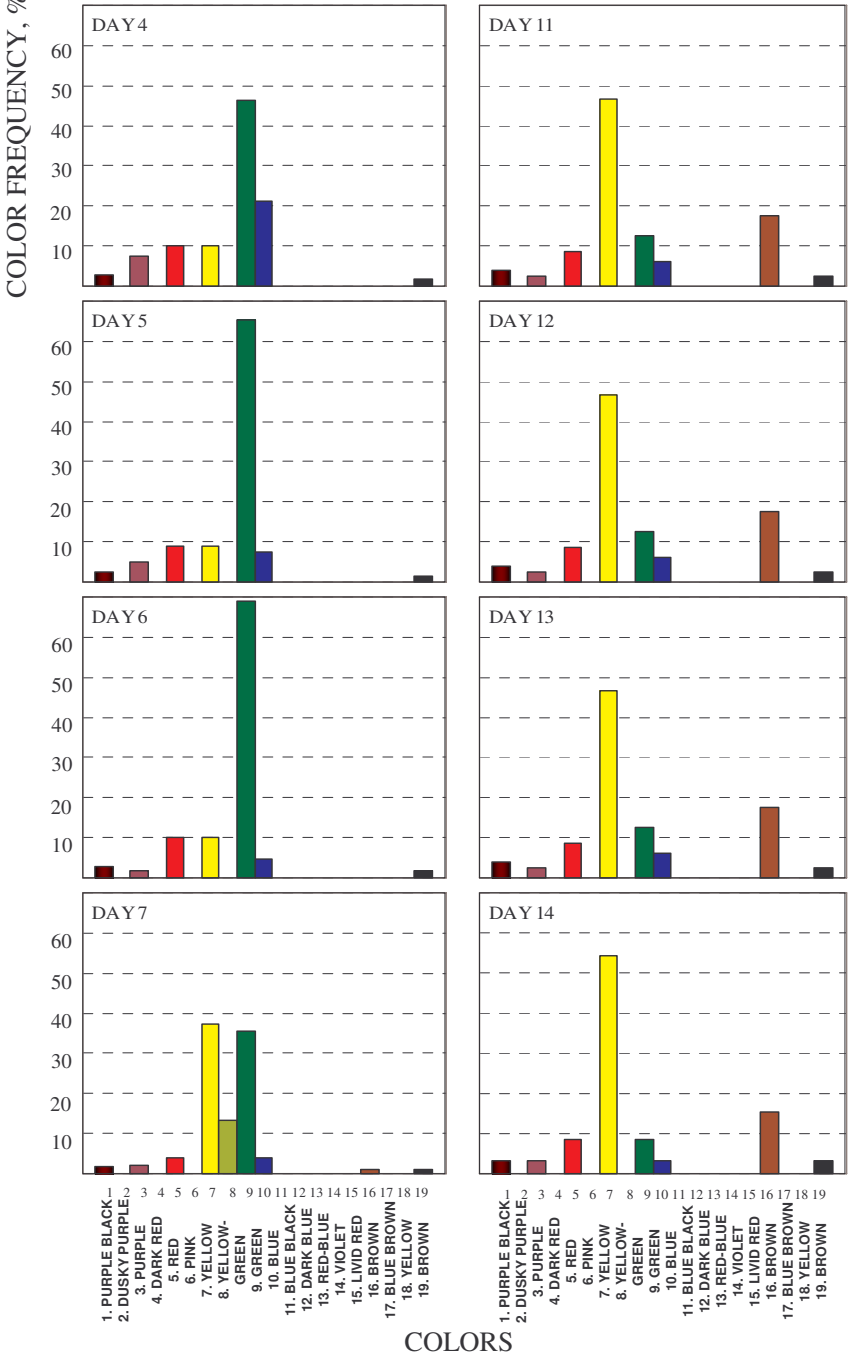

Fig.2. Graphical color representation of bruise aging as tabulated in Table II. The color map used is as given in Table I. 
- Day 2: There is no dominant color for day 2. Dark purple and purple, red, green, brown, and black have a $\%$ frequency above $10 \%$.

- Day 3: Blue is the dominant color with a \% frequency just below $30 \%$, followed by brown, dark purple, purple, and black, all with frequencies in the region of $10 \%$.

- Day 4: Green is the dominant color with a \% frequency close to $50 \%$, followed by blue, red and yellow with frequencies $20 \%, 10 \%$, and $10 \%$ respectively.

- Days 5 and 6: Green is highly dominant with a \% frequency close to $70 \%$, followed by red and yellow with a $\%$ frequency in the region of $10 \%$.

- Day 7: Both green and yellow are dominant with a \% frequency close to $35 \%$, followed by yellowgreen with a $\%$ frequency just above $10 \%$.

- Days 8-10: Yellow is highly dominant with a \% frequency close to $60 \%$, followed by green with a $\%$ frequency close to $15 \%$.

- Days 11-14: Yellow is still dominant but with a lower \% frequency of around $45 \%$, followed by brown with a $\%$ frequency just above $15 \%$.

\section{CONCLUDING REMARKS}

The determination of the age of a bruise is a very important task in forensic medicine. Estimation of the age of a bruise is based on the determination of the colors by visual inspection. This is a very subjective method; however this is the most widely used. In this paper, an attempt was made to review the different papers published in the literature, and derive color charts of daily bruise aging. Based on the color charts derived, the following observations can be made: (i) the bruise is red for Day 1 , (ii) there is no dominant color for Day 2, whereas for Day 3 , blue is becoming slightly dominant, (iii) green is becoming dominant for Days 4-6, with yellow color emerging, (iv) for Day 7, there is coexistence of green and yellow, (v) yellow is highly dominant for Days 7 to 14 , with brown emerging. Although there is a great variability in the color distribution proposed by the different studies, these charts can serve as guidelines for the qualitative evaluation of bruise imaging by visual analysis.

Clearly, the need exists for the quantitative analysis of bruise color imaging. However, the biggest problem that exists is the lack of a digital library with known bruises, classification, and color distribution. Bruise images have to be captured following a standardized protocol regarding illumination and settings for the digital camera. These images will have to be preprocessed via gamma correction to enable the standardized analysis. Images can then be segmented, although this is a very difficult task, and the experts input might be required.Color image analysis including texture analysis can then be carried to enable the characterization of bruises [24], [25].

\section{REFERENCES}

[1] R. Galbraith, "Heme oxygenase who needs it", Proc. Soc. Exp. Biol. Med., vol. 222, pp. 299-305, 1999.

[2] T. Stephenson, Y. Bialas, "Estimation of the age of bruising", Disease in Childhood, vol. 74, pp. 53-55, 1996

[3] L. Randeberg, A. Winnem, S. Blindheim, "Optical classification of bruises", Proceedings of SPIE, vol. 5312, pp. 54-64, 2004.

[4] N. Langlois, G. Gresham, "The ageing of bruises: a review and study of the colour changes with time", Forensic Science International, vol. 50, pp. 227-238, 1991.

[5] L. Munang, P. Leonard, J. Mok, "Lack of agreement on colour description between clinicians examining childhood bruising", Journal of Clinical Forensic Medicine, vol. 9, pp. 171-175, 2002.

[6] T. Stephenson, "Ageing of bruising in children", Journal of the Royal Society of Medicine, vol. 90, pp. 312-314, June 1997.

[7] S. Maguire, M. Mann, J. Sibert, "Can you age bruises accurately in children?", Arch. Dis. Child., vol. 90, pp. 187-189, 2005.

[8] A. Schwartz, Ricci L., "How accurately can bruises be aged in abused children? Literature review and synthesis", Pediatrics, vol. 97, pp. 254-261, February 1996.

[9] V. Hughes, P. Ellias, N. Ellis, N. Langlois, "The perception of yellow in bruise", Clinical Forensic Medicine, vol. 11, pp. 257 266, October 2004.

[10] E. Bariciak, A. Plint, I. Gaboury, "Dating of Bruises in Children: An Assessment of Physician Accuracy", Pediatrics, vol. 112, pp. 804-807, October 2003.

[11] S. Smith, F. S. Fiddes, "Forensic Medicine", Churchill, London, pp. 110-111, 1955.

[12] J. Glaister, "Medical Jurisprudence and Toxicology", E. \&S. Livingstone, Edinburgh, pp. 242-246, 1973.

[13] L. Adelson, "The pathology of homicide", Springfield: Charies C Thomas, pp. 382-386, 1974.

[14] F. Camps, "Gradwohl's Legal Medicine", 2nd ed., John Wright, Bristol, pp. 265, 1976.

[15] E. Rentoule, H. Smith "Glaister's medical jurisprudence and toxicology”, 13th ed. Edinburgh: Churchill Livingstone, pp. 242246, 1973.

[16] W. Spitz, R. Fisher, "Medicolegal investigation of death", 2nd ed., Springfield: Charies C Thomas, pp. 122-125, 1980.

[17] D. Sadle, D. Pounder "Injuries of medico-legal importance", lecture, University of Dundee, Department of Forensic Medicine, 1999 ,

http://www.dundee.ac.uk/forensicmedicine/llb/woundsdws.htm, last accessed March 2006.

[18] C. Polson, D. Gee, "The Essentials of Forensic Medicine", 4th ed. Oxford: Pergamon Press, pp. 97-105, 1984.

[19] A. Hasan, "Bruises", Self Care Guide, Emergency medical care, Pharmaceutical Services Division, Ministry of Health Malaysia, 2001, last accessed March 2006, http://www.pharmacy.gov.my/self_care_guide.

[20] E. Braunwald, A. Fauci, D. Kasper, "Harrison's Principles of Internal Medicine", 15th ed., McGraw-Hill, 2001.

[21] R. Farley, R. Reece, "Recognizing When a Child's Injury or Illness Is Caused by Abuse", U.S. Department of Justice, Office of Juvenile Justice and Delinquency Prevention, NCJ 160938, December 2002.

[22] J. Saxena, "Medicolegal Expert cum Toxicologist and Advocate", Medico-Legal Significance Of Bruise, last accessed March 2006, http://www.legalserviceindia.com/medicolegal/bruise.htm.

[23] L. Mosqueda, K. Burnight, S. Liao, "The life cycle of bruises in older adults", Journal of the American Geriatrics Society, vol. 53, pp. 1339-1343, August 2005.

[24] L. Georgieva, T. Dimitrova, N. Angelov, I. Stoynov, "Computeraided system for the bruise color's recognition", Proceedings of the International Conference CompSysTech'2005, Varna, Bulgaria, 6 pages, 2005.

[25] L. Georgieva, T. Dimitrova, N. Angelov, "RGB and HSV colour models in colour identification of digital trauma images", Proceedings of the International Conference CompSysTech'2005, Varna, Bulgaria, 6 pages, 2005. 